\title{
"The January barometer in emerging markets: new evidence from the Gulf Cooperation Council stock exchanges"
}

\begin{tabular}{|c|c|}
\hline AUTHORS & $\begin{array}{l}\text { Costas Siriopoulos iD https://orcid.org/0000-0003-1368-7182 } \\
\text { Layal Youssef }\end{array}$ \\
\hline ARTICLE INFO & $\begin{array}{l}\text { Costas Siriopoulos and Layal Youssef (2019). The January barometer in } \\
\text { emerging markets: new evidence from the Gulf Cooperation Council stock } \\
\text { exchanges. Investment Management and Financial Innovations, 16(4), 61-71. } \\
\text { doi:10.21511/imfi.16(4).2019.06 }\end{array}$ \\
\hline DOI & http://dx.doi.org/10.21511/imfi.16(4).2019.06 \\
\hline RELEASED ON & Tuesday, 26 November 2019 \\
\hline RECEIVED ON & Monday, 23 September 2019 \\
\hline \multirow[t]{2}{*}{ ACCEPTED ON } & Wednesday, 13 November 2019 \\
\hline & $((c))_{E Y}$ \\
\hline LICENSE & $\begin{array}{l}\text { This work is licensed under a Creative Commons Attribution } 4.0 \text { International } \\
\text { License }\end{array}$ \\
\hline JOURNAL & "Investment Management and Financial Innovations" \\
\hline ISSN PRINT & $1810-4967$ \\
\hline ISSN ONLINE & $1812-9358$ \\
\hline PUBLISHER & LLC "Consulting Publishing Company "Business Perspectives" \\
\hline FOUNDER & LLC "Consulting Publishing Company "Business Perspectives" \\
\hline
\end{tabular}

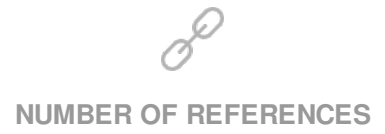

43
NUMBER OF FIGURES

1
NUMBER OF TABLES

4

(C) The author(s) 2023. This publication is an open access article. 


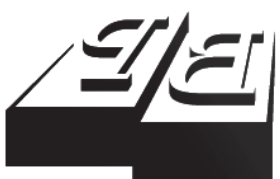

BUSINESS PERSPECTIVES

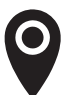

LLC "CPC "Business Perspectives" Hryhorii Skovoroda lane, 10, Sumy, 40022, Ukraine

www.businessperspectives.org

Received on: $23^{\text {rd }}$ of September, 2019 Accepted on: $13^{\text {th }}$ of November, 2019

(c) Costas Siriopoulos

Layal Youssef, 2019

Costas Siriopoulos, Ph.D., Professor of Finance, College of Business, Zayed University, UAE.

Layal Youssef, Bsc., Msc., Instructor, College of Business, Zayed University, UAE.

\section{() (i)}

This is an Open Access article, distributed under the terms of the Creative Commons Attribution 4.0 International license, which permits unrestricted re-use, distribution, and reproduction in any medium, provided the original work is properly cited.

\title{
THE JANUARY BAROMETER IN EMERGING MARKETS: NEW EVIDENCE FROM THE GULF COOPERATION COUNCIL STOCK EXCHANGES
}

\begin{abstract}
International investors' interest in the capital markets in the region of Gulf countries has dramatically increased in last two decades. Thus, it would be motivating to investigate their characteristics, where the January anomaly is a major one. This paper studies the veracity of the January effect rule in the Gulf Cooperation Council (GCC) stock markets and examines the predictive power of January returns. Seven GCC stock markets are tested - the market indices in Bahrain, Abu Dhabi, Dubai, Kuwait, Oman, Qatar, and Saudi Arabia - from January 1, 2001 until December 31, 2018, a timeframe which has rarely been analyzed. Ordinary least square (OLS)-based dummy variable regression equation was used as the conventional econometric procedure in the works of financial calendar anomalies in stock markets. Some evidence is reported for the markets of Dubai and Kuwait. The paper also provides an additional explanation for the performance of stock market of Kuwait. The findings are opposite to the well documented evidence that emerging markets are less efficient and hence it is likely that several market anomalies are further pronounced. The results suggest that the predictive power of the January anomaly can be considered as a temporary anomaly in the GCC markets, since it is concentrated in only a couple of GCC markets and does not persist in time.
\end{abstract}

Keywords

\section{JEL Classification}

\section{INTRODUCTION}

There are many market anomalies distinguished and reported in the stock market literature. Calendar effects in stock market returns have confused financial economists since the mid-70s (e.g., Mills, Siriopoulos, Markellos, \& Harizanis, 2000). Some of the stock market seasonality's are relatively easy to identify, reliable and testable data are supplied, and to have knowledge about their statistical significance might be of importance for analysts, traders, portfolio managers and news observers and reporters. In particular, "January effect", which is a pattern that the mean return of stocks is higher in January, has been one of the most investigated topics in market finance, since Kinney and Rozeff (1976) reported evidence that stocks in general generate statistically significant higher returns in January comparing to the remaining other months during the year.

January has a significant amazing notoriety on Wall Street as a deluge of money structure year-end rewards, and yearly assignments commonly drive stocks higher. We have seen many research subjects on such abnormalities in the US and the major European markets, but few in emerging markets. It is expected that many well-recognized stock 
market anomalies are not present in the emerging stock exchanges, thus, developing markets provide an interesting "out of sample" test profit-generating calendar effects of calendar anomalies (Claessens, Dooley, \& Warner, 1995). Nevertheless, this sort of study has been seldom inspected inside the Middle East, especially in the Gulf Cooperation Council (GCC) region. Their market capitalization to GDP are comparable to that of other emerging markets, although they vary significantly in the degree of foreign investors participation (the UAE has the highest participation of foreign investors and Saudi Arabia is the lowest, but the largest equity market in the Arab world). Although GCC groups together six of the world's wealthiest nations, have functioning stock markets open to foreign investors, and some of them having graduated into the Morgan Stanley Capital International (MSCI) emerging markets category, they are still not studied enough. This is because in the past, these markets turned out to be generally ignored by international investors due to imposed limitations and other restrictions on foreign stock ownership, the absence of common accounting and reporting standards and corporate transparency or based on the political uncertainty and economic turbulence at the end of the first decade of 2000 and/ or due to the difficulty of obtaining adequate and consistent market data.

Given the increasing importance of financial and trade relationships between GCC and advanced economies, and the increased interest of international investors in these markets nowadays, it would be reasonable to study the characteristics of these markets, where the January anomaly is a major one. This paper studies the other January effect (OJE) and its variations in the small emerging markets of the GCC region. The paper applies ordinary least square (OLS)-based dummy variable regression equation as the conventional methodology in the literature of anomalies (Arshad \& Coutts, 1997; Mills et al., 2000), although several econometric techniques have been applied over time (Harshita, Singh, \& Yadav, 2019) with mixed results. In our analysis, the January effect is not evidenced in the Arab countries of the Gulf, except for Dubai and Kuwait. Since this paper finds that the OJE is concentrated in only a couple of GCC markets and does not persist in time, it can be considered as a temporary anomaly (Schwert, 2002; Stivers, L. Sun, \& Y. Sun, 2009).

Although various explanations for the January effect have been considered in the literature, no final clarification has been given to distinguish a particular explanation from others (Dodd \& Gakhovich, 2011; Chen, 2012). Because calendar anomalies in stock markets appear quite easy and low cost to exploit, their sustained existence seems incomprehensible. In fact, there are no unanimously recognized interpretations for calendar anomalies such as the January effect, and a number of factors are contributing: sample selection, data mining, measurement errors, alterations in settlement time of transactions, taxation, small-cap stocks, riskiness of the stock, company type, bid-ask spread and thin trading. A related statistical interpretation for the January effect is commonly referred to as the "data-snooping hypothesis" (Haug \& Hirschey, 2006), according to which much, if not all, of the January effect may be a statistical artifact linked with the investment selection on a specific calendar period. On the other hand, there are periods of calendar time when the investors' behavior changes significantly. To give some examples, as noted in Mills et al. (2000), "we can have a change in the mean, the variance, the skewness, or the kurtosis of the returns' distribution, only for the periods the effect is observed." Besides it might be the case that a calendar anomaly is simply the effect of another's calendar anomaly (Jacobs \& Levy, 1988 ) in disguise. Thus, the interaction of different calendar anomalies extends the set of possible explanations. In this paper, the interaction of the other January effect with the Halloween effect is also investigated. In the paper, the evidence that for the stock exchanges of Kuwait and Saudi Arabia Halloween effect is an explanation of the OJE is reported.

Overall, the empirical findings do not allow us to support the OJE in the GCC region, although regularities are observed for a couple of countries. The results of this paper are opposite to the well-documented evidence that smaller markets are best candidates for market anomalies and seasonality is due to their informational inefficiency. In contrast, the findings provide additional evidence that January effect does not exist anymore in stock return (Patel, 2015), but are in accordance with the study of Al-Saad (2004) 
who reported the January effect in the Kuwait stock market and concluded that taxes are not the fundamental source of seasonality.

The structure of the paper is as follows. In the next section a literature review of the January effect with the focus in the GCC stock exchanges is presented. In section 2, model specifications are developed and a discussion of the empirical findings in GCC markets is offered. The paper concludes in the last section along with the main findings and directions for future research.

\section{LITERATURE REVIEW}

The OJE was first discovered for the US by Hirsch (1972) and labeled the "January barometer" (JB). Hirsch and Hirsch (2007) report a 91.1\% accuracy ratio for this barometer for S\&P 500 data since 1950 and explain this phenomenon by major political events that occur in January as being responsible for its presence. Fuller (1978) examined the JB in comparison with the 5-day hypothesis for the years 1929-1977 and found that for both DJIA and S\&P500, the JB correctly forecasted $81 \%$ of cases compared to $78 \%$ for the 5 -day rule. By studying various periods, he showed that JB is just slightly better at forecasting full-year returns than the 5 -day rule, but he concluded that both theories do not help in implanting a profitable trading strategy. Bloch and Pupp (1983) examined two different versions of the January predictive hypothesis for the period 1950-1982 and provided evidence against the hypothesis. Brown and Luo (2006), using the data between 1941 and 2002, tested three different variations of the January barometer hypothesis and concluded that January clearly is worth in forecasting the next twelve months than any other month of the year. Fuller (1978) calculated the returns of the remaining 11 months, while Brown and Luo (2006) have considered the next 12-month period. Recently, Cooper, Mcconnell, and Ovtchinnikov (2006) confirmed the wisdom "as goes January, so goes the year" in the US stock market for the period 1940-2003 and found that macroeconomic/ business cycle variables did not explain OJE nor is caused by the presidential cycle. In a recent paper, however, Darrat, Li, and Chung (2013) showed that the OJE disappears in the US market once they expand the period from 1926 to 2012. Bohl and Salm (2010) and not provide evidence of the OJE in 18 international capital markets.

The reasons for January effect have been discussed by many researchers and the most popular one is "tax-loss-selling hypothesis", first proposed in 1942 by Wachtel ("stocks rose in January as investors began buying again after the year-end tax-induced sell-off"). According to a similar hypothesis for the January effect, namely the "new-year resolution hypothesis", people restructure their portfolios and habits in December or January (Ritter, 1988), and their plans or investment decisions are implemented in January and, as a result, January prices go up. Both hypotheses state that stock prices experience a drop at the year-end as a result of investors' realizing losses or comprehending year-end bonuses to reduce their tax, and then return to equilibrium levels after year-end, leading to an abnormally high return in January. Hence, the January effect should not exist in countries where there is no capital gains tax, or the tax year does not start in January. January effect is also less pronounced as many investors now use tax-protected retirement schemes like IRAs and 401(k). However, Al-Saad (2004) studied the OJE in the Kuwait Stock Exchange and concluded that taxation is not the reason for the appearance of the January effect. The findings of this paper also support the existence of OJE in the Kuwait Stock Exchange for the period from January 2001 to December 2018.

Wachtel (1942) advanced an alternative January effect, the "Santa Claus effect," and supported the hypothesis that the unusual demand for cash for the holiday season affects the investors to sell the stocks in December, which is consistent with the increasing sales during December. Then, prices are expected to rise in January. Recently, Washer, Nippani, and Johnson (2016) show that Santa Claus Rally exists for a long period of time (1916-2014) in the USA. Another explanation discussed is the "window dressing hypothesis": at the end of each year, portfolio managers and other institutional investors liquidate losing positions and show only profitable stocks in their portfolios to attract 
more investors. Then, in January small-cap, riskier stocks with the hope of making a profit, thus, raising the January prices (Haugen \& Lakonishok, 1988). However, in a recent study, Patel (2012) offers the evidence from the US stock market that small firms did not generate significantly higher returns in January over the remaining months of the year.

Yet, another January anomaly is also related to "January barometer" and the " 5 -day rule" and both confirm the January effect. Hence, January market anomaly is also used in the literature under other cases known as other January effects (Cooper, Mcconnell, \& Ovtchinnikov, 2006). January returns (first five days of January) specify the return of the remaining months and/or year's return. This is sometimes called the "January predictor" or "January barometer" (" 5 -day rule"). This paper investigates January barometer hypothesis in the GCC region for the period from January 2001 to December 2018. Based on the empirical results of the paper, one cannot support that the January effect does seem to be a GCC regional phenomenon, with two-three exceptions, thus, confirming Claessens et al.'s (1995) argument that the familiar stock market anomalies are not present in the emerging capital markets.

Although various explanations for the January effect have been considered in the literature, no final clarification has been given to distinguish a particular explanation from others (Dodd \& Gakhovich, 2011; Chen, 2012). Because calendar anomalies appear relatively easy and low cost to exploit, their continued (in-) existence seems inexplicable. In fact, there are no universally accepted explanations for calendar anomalies such as the January effect, and a number of factors have been found as potential contributors: sample selection, data mining, measurement errors, differences in settlement time of transactions, taxes, small-cap stocks, riskiness of the stock, company type, bid-ask spread and thin trading. A related statistical explanation for the January effect is commonly referred to as the "data-snooping hypothesis" (Haug \& Hirschey, 2006), according to which much, if not all, of the January effect may be a statistical artifact tied to investment period selection. On the other hand, there are periods when the investors' behavior changes significantly. To give some examples, we can have a change in the mean, the variance, the skewness, or the kurtosis of the returns' distribution, only for the periods the effect is observed (Mills et al., 2000). Besides, it might be the case that a calendar anomaly is simply the effect of another's calendar anomaly (Jacobs \& Levy, 1988) in disguise. Thus, the interaction of different calendar anomalies extends the set of possible explanations. In this paper, the interaction of the other January effect with the Halloween effect is also investigated. The paper provides evidence that for the stock exchanges of Kuwait and Saudi Arabia, Halloween effect is an explanation of the OJE.

Because of the difficulty of obtaining enough and adequate stock market data, no attention has been paid by researchers to these markets. Therefore, the sporadic research on GCC financial markets was conducted on either individual stock exchanges or a limited set of capital markets of the Middle East and North African (MENA) region (for instance, Bley \& Chen, 2006; Zarour, 2006; Zarour, 2007; Zarour \& Siriopoulos, 2008; Chaffai \& Medhioub, 2018). The efficiency of GCC financial markets was investigated earlier, and the results of previous studies indicated the support of market inefficiency. GCC stock markets are characterized by various trades with different time horizon strategies, and various information flows due to the high concentration of the markets. Yet, economic structural changes, ongoing regulatory reforms, and market liberalization in the GCC economies have an impact on investors' portfolio choice for diversification purposes, leading to boosted market capitalization, average daily turnover, and IPO activity, since 2002 (PWC, 2019).

So now investors have a greater interest in diversifying their portfolios to these markets, and investigating the distinguished characteristics of these markets is highly worthy, as market anomalies affect the trading and portfolio decisions. Bulter and Malikah (1992) studied the efficiency of Saudi and Kuwaiti stock markets for the period 1985-1989. Other studies refer to Saudi Arabia market (Nourredine, 1998), UAE (Ebid, 1990) or some MENA countries (Zarour, 2006, 2007). This 
is due to the stock markets in the GCC being rather small, and listed companies are few and most stocks are occasionally traded, with a low trading activity.

To conclude this short review of January anomaly, it is important to note the implications for the efficient market hypothesis, which infers that stock returns are unpredictable. In the presence of a calendar anomaly, different methods may improve the out-of-sample forecasting ability. However, this is not proof of market inefficiency, but evidence that market efficiency, like all theories, is fundamentally flawed (Ball, 1994). If a time series is not affected by a calendar regularity at all, the forecasting is not ameliorated much (Aly, Mehdian, \& Perry, 2004; Leontitsis \& Siriopoulos, 2006a, b). This is in favor of the concept that once a market's anomaly effect becomes widely acknowledged, then, excess risk-adjusted returns disappear, which is supported by the market efficiency theory. An additional area of interest is the interaction of different calendar anomalies, addressed by Jacobs and Levy (1988), which extends the set of possible explanations for a market anomaly. Hence, possibly, the effect of a particular calendar anomaly may be simply the effect of another's calendar anomaly in disguise. In this paper, it is also investigated whether the OJE is simply the Halloween effect ("sell in May and go away," advanced by Bouman \& Jacobsen, 2002) in disguise. Empirical evidence that for the stock exchanges of Kuwait and Saudi Arabia, Halloween effect is an explanation of the OJE is conveyed.

In this paper, we explore the possible presence of the January barometer in a sample of the Gulf Cooperation Council (GCC) stock markets of Saudi Arabia, Abu Dhabi, Dubai, Kuwait, Bahrain, Oman, and Qatar. The analysis of these financial markets is based on daily returns of their biggest respective indices during the timeframe from January 1, 2001 until December 31, 2018, which is a timeframe not well covered in previous research. Due to the GCC and its creating status, it very well may be normal, given the past writing, that probably a portion of the broke down business sectors will demonstrate a specific measure of wasteful as- pects, for example, they will dismiss the productive market speculation.

\section{MODEL SPECIFICATIONS AND EMPIRICAL RESULTS}

The data are composed of daily closing values of the major indices of the seven Gulf regions, which include indices representing the GCC. According to data from Bloomberg, the length of the time series varies from country to country and from index to index. For instance, KWSEIDX (Kuwait), MSM30 (Oman), DSM (Qatar) and SASEIDX (Saudi Arabia) have longer time series than the other markets, by which their data start from 2001, whereas ADSMI (Abu Dhabi) starts from 2002, DFM (Dubai) and BHSEASI (Bahrain) start from 2004.

The analysis was performed using the entire data set for each index. Monthly returns were calculated using daily closing prices. The data were then grouped by month (from January to December).

$\operatorname{Daily} \operatorname{Return}(T)=\frac{\text { Closing value }(T)}{\text { Closing value }(T-1)}-1$.

The monthly return was calculated by using the daily return for the months of December and January, was captured by using the first day of the month and the last day of the same month ${ }^{1}$.

Table 1 presents the descriptive statistics of the indices studied. The stock markets of Dubai, Kuwait, Qatar, Bahrain, and Saudi Arabia have negative skewness. Literature documents that aggregate stock market returns exhibit asymmetric volatility, which explains the propensity for volatility in these markets to exhibit negative returns with greater probability than the one suggested by the normal distribution (see also Figure 1 after 2008).

This effect leads to an increase of the required risk premia and it might clarify the low returns of these markets. The markets of Oman and Abu Dhabi are riskier and Bahrain stock market exhibits the lowest risk.

1 All data were extracted from Bloomberg terminal from the year the index was listed. Some of the indices were not listed on the terminal before 2004, such as Bahrain and Dubai. Therefore, there are no data in Table 1 before the mentioned year. 
Table 1. Descriptive statistics

\begin{tabular}{|c|c|c|c|c|c|c|c|}
\hline Statistical measures & ADSM & DFMGI & KWSEIDX & DSM & BHSEASI & MSM30 & SASEIDX \\
\hline Mean & 0.015043921 & 0.00325 & 0.00664 & 0.008044 & -0.00138 & 0.0383 & 0.00546 \\
\hline Standard error & 0.007165261 & 0.007049 & 0.003336 & 0.005023 & 0.002557 & 0.036648 & 0.004755 \\
\hline Median & 0.009502942 & -0.00324 & 0.012085 & 0.007781 & 0.000256 & 0.004113 & 0.008462 \\
\hline Mode & N/A & -0.0064 & N/A & N/A & N/A & 0.037841 & 0.027852 \\
\hline Standard deviation & 0.1023404 & 0.094568 & 0.049361 & 0.073826 & 0.033138 & 0.538617 & 0.069878 \\
\hline Sample variance & 0.010473558 & 0.008943 & 0.002437 & 0.00545 & 0.001098 & 0.290108 & 0.004883 \\
\hline Kurtosis & 90.0651084 & 2.642483 & 3.193497 & 1.966064 & 2.123184 & 212.2872 & 1.843318 \\
\hline Skewness & 7.843134906 & -0.03447 & -0.59526 & -0.4839 & -0.43198 & 14.50723 & -0.70198 \\
\hline Range & 1.400208238 & 0.723298 & 0.40983 & 0.523596 & 0.223996 & 8.168889 & 0.453631 \\
\hline Minimum & -0.197388181 & -0.40822 & -0.23471 & -0.27789 & -0.13501 & -0.28483 & -0.27757 \\
\hline Maximum & 1.202820056 & 0.315081 & 0.175119 & 0.245706 & 0.088983 & 7.884057 & 0.176058 \\
\hline Sum & 3.068959933 & 0.58495 & 1.454179 & 1.73753 & -0.23254 & 8.272871 & 1.179259 \\
\hline Count & 204 & 180 & 219 & 216 & 168 & 216 & 216 \\
\hline Confidence level (95\%) & 0.014127881 & 0.013909 & 0.006574 & 0.009901 & 0.005048 & 0.072236 & 0.009372 \\
\hline
\end{tabular}

By looking at Table 2, different monthly perfor- the loss. Another example is that in 2017, ADSM mance for each index is observed. For instance, in was showing a low but positive return in January, 2016, all indices tested in this paper were under- in the same year, by December, the return did not performing with a loss in returns in January. By show improvement, however, it took a turn to the December, indices were slightly recovering from worst.

Table 2. Monthly returns on closing prices of GCC market indices (2000-2018)

\begin{tabular}{|c|c|c|c|c|c|c|c|c|}
\hline \multirow{2}{*}{ Year } & \multirow{2}{*}{ Month } & \multicolumn{7}{|c|}{ Daily returns on closing prices of GCC market indices } \\
\hline & & ADSM & DFM & MSM30 & SASEIDX & BHSEASI & KWSEIDX & DSM \\
\hline \multirow{2}{*}{2018} & January & $-4.37 \%$ & $-0.79 \%$ & $-0.35 \%$ & $-0.77 \%$ & $-1.17 \%$ & $-2.71 \%$ & $0.81 \%$ \\
\hline & December & $1.88 \%$ & $2.37 \%$ & $-0.41 \%$ & $0.22 \%$ & $0.36 \%$ & $0.45 \%$ & $0.15 \%$ \\
\hline \multirow{2}{*}{2017} & January & $-3.53 \%$ & $2.08 \%$ & $-0.99 \%$ & $-3.19 \%$ & $-6.37 \%$ & $0.86 \%$ & $-2.05 \%$ \\
\hline & December & $0.66 \%$ & $0.72 \%$ & $1.03 \%$ & $-0.06 \%$ & $1.95 \%$ & $0.57 \%$ & $-0.03 \%$ \\
\hline \multirow{2}{*}{2016} & January & $1.35 \%$ & $1.92 \%$ & $-4.83 \%$ & $-8.87 \%$ & $1.94 \%$ & $0.65 \%$ & $1.01 \%$ \\
\hline & December & $1.66 \%$ & $0.32 \%$ & $0.31 \%$ & $-0.42 \%$ & $0.58 \%$ & $-0.09 \%$ & $0.96 \%$ \\
\hline \multirow{2}{*}{2015} & January & $-1.70 \%$ & $-1.89 \%$ & $3.90 \%$ & $1.03 \%$ & $-0.98 \%$ & $1.83 \%$ & $-8.28 \%$ \\
\hline & December & $0.73 \%$ & $0.02 \%$ & $-0.70 \%$ & $0.08 \%$ & $0.90 \%$ & $0.04 \%$ & $-0.06 \%$ \\
\hline \multirow{2}{*}{2014} & January & $-4.06 \%$ & $-0.44 \%$ & $1.61 \%$ & $-0.38 \%$ & $-8.59 \%$ & $-1.83 \%$ & $-1.55 \%$ \\
\hline & December & $1.89 \%$ & $1.29 \%$ & $2.02 \%$ & $-1.82 \%$ & $0.74 \%$ & $0.39 \%$ & $-0.34 \%$ \\
\hline \multirow{2}{*}{2013} & January & $-1.04 \%$ & $-0.26 \%$ & $1.90 \%$ & $-0.37 \%$ & $-6.90 \%$ & $-1.05 \%$ & $-1.14 \%$ \\
\hline & December & $0.30 \%$ & $1.13 \%$ & $0.27 \%$ & $0.18 \%$ & $1.59 \%$ & $0.11 \%$ & $0.11 \%$ \\
\hline \multirow{2}{*}{2012} & January & $0.84 \%$ & $0.16 \%$ & $-0.19 \%$ & $-2.85 \%$ & $-1.00 \%$ & $-1.85 \%$ & $-8.99 \%$ \\
\hline & December & $0.15 \%$ & $-0.40 \%$ & $0.54 \%$ & $-0.03 \%$ & $-0.80 \%$ & $-0.22 \%$ & $0.70 \%$ \\
\hline \multirow{2}{*}{2011} & January & $-1.21 \%$ & $-0.62 \%$ & $-0.44 \%$ & $-1.09 \%$ & $-2.45 \%$ & $-1.35 \%$ & $-1.07 \%$ \\
\hline & December & $1.51 \%$ & $0.51 \%$ & $0.28 \%$ & $0.28 \%$ & $-0.11 \%$ & $0.47 \%$ & $-0.38 \%$ \\
\hline \multirow{2}{*}{2010} & January & $-1.17 \%$ & $-1.28 \%$ & $-0.24 \%$ & $-0.24 \%$ & $-1.31 \%$ & $-1.37 \%$ & $-2.19 \%$ \\
\hline & December & $0.65 \%$ & $0.54 \%$ & $0.14 \%$ & $0.06 \%$ & $0.33 \%$ & $-0.10 \%$ & $0.20 \%$ \\
\hline \multirow{2}{*}{2009} & January & $-1.08 \%$ & $-1.32 \%$ & $-1.13 \%$ & $-0.88 \%$ & $0.01 \%$ & $-1.07 \%$ & $1.11 \%$ \\
\hline & December & $-0.07 \%$ & $-0.37 \%$ & $0.22 \%$ & $-3.36 \%$ & $0.66 \%$ & $0.27 \%$ & $-0.46 \%$ \\
\hline \multirow{2}{*}{2008} & January & $-1.24 \%$ & $-2.03 \%$ & $-0.57 \%$ & $-0.81 \%$ & $-0.06 \%$ & $-2.09 \%$ & $1.92 \%$ \\
\hline & December & $1.45 \%$ & $-0.19 \%$ & $4.30 \%$ & $0.24 \%$ & $-0.84 \%$ & $-2.69 \%$ & $1.43 \%$ \\
\hline \multirow{2}{*}{2007} & January & $2.64 \%$ & $-4.49 \%$ & $-1.09 \%$ & $-0.88 \%$ & $0.32 \%$ & $0.22 \%$ & $2.38 \%$ \\
\hline & December & $-0.64 \%$ & $-1.16 \%$ & $1.10 \%$ & $-0.50 \%$ & $0.79 \%$ & $0.40 \%$ & $-1.21 \%$ \\
\hline \multirow{2}{*}{2006} & January & $-0.56 \%$ & $-0.62 \%$ & $-0.29 \%$ & $-0.06 \%$ & $-0.15 \%$ & $1.96 \%$ & $-0.64 \%$ \\
\hline & December & $0.94 \%$ & $1.21 \%$ & $0.17 \%$ & $1.68 \%$ & $2.10 \%$ & $1.06 \%$ & $1.13 \%$ \\
\hline \multirow{2}{*}{2005} & January & $-0.31 \%$ & $-1.20 \%$ & $-0.20 \%$ & $-1.19 \%$ & $1.23 \%$ & $-1.10 \%$ & $-1.86 \%$ \\
\hline & December & $0.41 \%$ & $0.20 \%$ & $0.05 \%$ & $0.08 \%$ & $0.51 \%$ & $0.26 \%$ & $0.90 \%$ \\
\hline \multirow{2}{*}{2004} & January & $0.69 \%$ & $-0.34 \%$ & $0.96 \%$ & $-2.79 \%$ & - & $-1.04 \%$ & $0.63 \%$ \\
\hline & December & $0.36 \%$ & $1.06 \%$ & $1.29 \%$ & $0.89 \%$ & $0.54 \%$ & $0.38 \%$ & $0.01 \%$ \\
\hline \multirow{2}{*}{2003} & January & $-12.50 \%$ & - & $-1.77 \%$ & $-0.73 \%$ & - & $-0.92 \%$ & $-0.08 \%$ \\
\hline & December & $0.55 \%$ & - & $0.24 \%$ & $0.38 \%$ & - & $-0.60 \%$ & $0.54 \%$ \\
\hline \multirow{2}{*}{2002} & January & $-2.11 \%$ & - & $2.80 \%$ & $-0.74 \%$ & - & $0.74 \%$ & $-2.33 \%$ \\
\hline & December & $-0.13 \%$ & - & $-0.21 \%$ & $0.34 \%$ & - & $0.32 \%$ & $-0.12 \%$ \\
\hline \multirow{2}{*}{2001} & January & - & - & $16.62 \%$ & $-0.04 \%$ & - & $-1.48 \%$ & $-0.17 \%$ \\
\hline & December & $0.55 \%$ & - & $1.10 \%$ & $-0.16 \%$ & - & $-0.04 \%$ & $0.42 \%$ \\
\hline \multirow{2}{*}{2000} & January & - & - & - & - & - & $-0.25 \%$ & - \\
\hline & December & - & - & $-0.59 \%$ & - & - & $0.12 \%$ & - \\
\hline
\end{tabular}




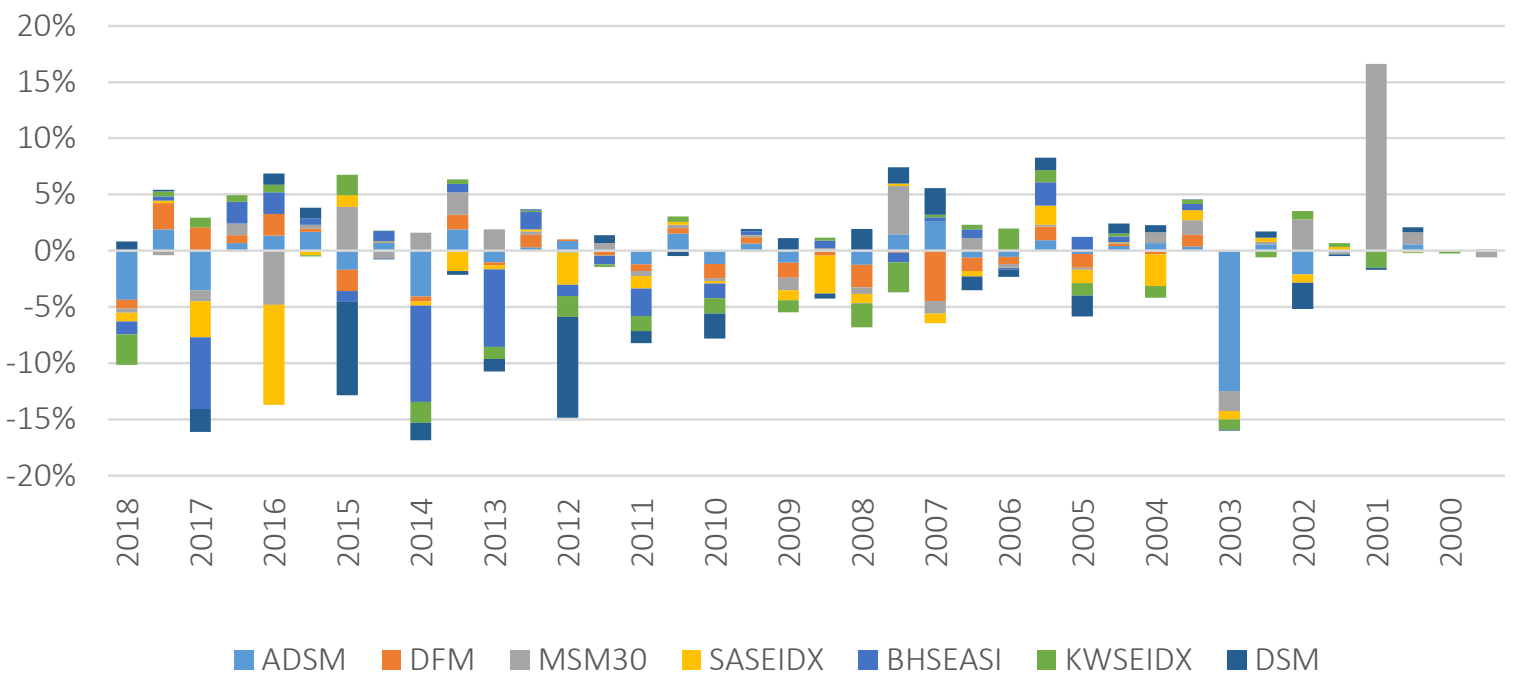

Figure 1. GCC market performance for the period 2000-2018

Figure 1 depicts the annual performance of the GCC stock market indices for the period under study. In the period after 2008, returns are mostly negative and the markets are more active.

Table 3 witnesses that the correlations of return between the GCC stock markets are not strong enough. The strongest correlation is observed in the pairs of Bahrain and Oman stock markets (0.804), Bahrain and Kuwait (0.7787), and Kuwait and Abu Dhabi $(0.6259)$ stock exchanges. The correlation structure for all other markets is not strong and especially for Qatar with all other GCC exchanges. Specifically, the lowest correlation coefficient is observed between the market returns of Abu Dhabi and Saudi Arabia (0.0024). The correlation of returns between the GCC stock indices shows a very weak trend behavior in these markets. The structure of correlations between stock returns also shows that the markets are not volatile.

\subsection{Analysis of market returns following positive and negative January's}

This paper formally tests the statistical significance of the January barometer by running a regression analysis using five different models generated from the general equation: $y_{t+1}=a+b x_{t}+e$, where $y_{t+1}$ is the dependent variable, that is, the 11-month and 12-month period after January, $x_{t}$ is the independent variable, that is, a dummy variable for January or the return of January, and $e$ represents the error term. The regression equations are estimated using (OLS)-based dummy variable regression model as the standard approach in the literature of capital market anomalies (Haugen \& Jorion, 1996; Arshad \& Coutts, 1997; Mills et al., 2000; Bohl \& Salm, 2010). The standard errors are adjusted for heteroskedasticity and autocorrelation in the residuals using the methods proposed

Table 3. Correlation structure in the GCC stock markets

\begin{tabular}{|c|c|c|c|c|c|c|c|}
\hline & ADSMI & DFM & MSM30 & SASEIDX & BHSEASI & KWSEIDX & DSM \\
\hline ADSMI & 1 & & & & & & \\
\hline DFM & 0.315252 & 1 & & & & & \\
\hline MSM30 & 0.166867 & 0.470097 & 1 & & & & \\
\hline SASEIDX & 0.002394 & 0.247549 & 0.440329 & 1 & & & \\
\hline BHSEASI & 0.475444 & 0.541177 & 0.803972 & 0.43984 & 1 & & \\
\hline KWSEIDX & 0.625849 & 0.439054 & 0.582802 & 0.268314 & 0.778645 & 1 & \\
\hline DSM & 0.134305 & 0.388366 & 0.349172 & 0.374611 & 0.401006 & 0.403658 & 1 \\
\hline
\end{tabular}


by Breusch-Pagan-Godfrey and Breusch-Godfrey, respectively.

The null hypothesis is that the spread in returns between positive and negative January returns is significantly different from zero. Slope coefficient $b$ was used as indicator for the spread following Marshall and Visaltanachoti (2010) ${ }^{2}$. Therefore, if the slope coefficient is positive and significantly different from zero, this is an evidence supporting OJE, as this would indicate the eleven months (Model 1) or twelve months return (Model 2 and Model 4), following a positive January return is significantly larger than the eleven months or twelve months return following a negative January return ${ }^{3}$.

\section{Model 1}

$$
R_{t}^{F e b-D e c}=a+b D_{t}^{J a n}+e_{t},
$$

where the dependent variable $R_{t}^{F e b-D e c}$ is the 11 month return from February to December in year $t$ for the respective country, $D_{t}^{J a n}$ is a January dummy variable, which has value 1 if the January return in year $t$ for the respective country is positive and has value 0 otherwise. A statistically significant and different from 0 coefficient of the dummy variable implies that January stock returns predict the returns in the following eleven months. The analysis is performed on all seven markets and the results for Model 1 are reported in Table 4 along with the $p$-values. The findings show that $b$ (the spread parameter) is positive and statistically significant only for the market of Kuwait. In general, coefficients are not statistically significant point estimates and half of them do not have the theoretically expected signs.

This implies that the hypothesis that the OJE has predictive power for the returns in the subsequent eleven months for all the GCC exchanges cannot be supported, with the only exception of the Kuwait Stock Exchange. This finding is in agreement with the results obtained in Al-Saad (2004).
With Model 2, we check over 12-month period the returns, where the dependent variable $R_{t}^{\mathrm{Feb}_{t}-\mathrm{Jan}_{t+1}}$ is the excess return from February to January of the following year.

\section{Model 2}

$$
R_{t}^{F e b_{t}-J a n_{t+1}}=a+b D_{t}^{J a n_{t}}+e_{t} .
$$

We observe the same results as in Model 1 where $b$ is positive in most markets, but statistically insignificant. Hence, the OJE hypothesis could not be supported.

According to Stivers et al. (2009), using a dummy variable as in Model 1 or Model 2 could cause much formation included in the January returns to be lost. Therefore, we estimate Model 3, where instead of the dummy variable $D$, we use the returns of January, which capture all the return information included in the January returns ${ }^{4}$.

\section{Model 3}

$$
R_{t}^{F e b-D e c}=a+b R_{t}^{\mathrm{Jan}}+e_{t} .
$$

Under this model specification, a significant and positive $b$ would indicate that the subsequent eleven months return varies positively with the January return for the respective country, which is another way of describing the January barometer. Even in this model specification, the results are not conclusive for the markets in GCC. Positive and statistically significant slopes are observed for the stock markets of Dubai and Kuwait, but for none of the other markets.

In order to test whether OJE has any predictive power over the following 12-month period, we are using the strategy of holding long (short) position for 12-months following positive (negative) January's (Marshall \& Visaltanachoti, 2010).

2 Marshall and Visaltanachoti (2010) showed that the "simple spread" method from Cooper et al. (2006) is inaccurate.

3 Investors interpret the OJE based on raw returns rather than on excess returns. Therefore, in this study, we use the raw returns. Continuously compounded excess return is also applied:

Excess return $=\ln \left[\left(\frac{I_{t}}{I_{t-1}}\right)-\ln \left(1+\frac{i}{12 \cdot 100}\right)\right] \cdot 100$,

where is the value of the index at time $\mathrm{t}, \mathrm{i}$ is the risk-free rate, and $\ln (\mathrm{x})$ is the natural logarithm of $\mathrm{x}$, but the results did not vary significantly.

4 It should be noted that in the case of Model 3, the b coefficient cannot be interpreted, as the spread because the value of the January returns is not either 1 , in case of a positive January return, or 0 , otherwise. 
Table 4. Estimated parameters

\begin{tabular}{|c|c|c|c|c|c|c|c|c|c|c|c|c|}
\hline \multirow{2}{*}{ Country } & \multirow{2}{*}{$\begin{array}{l}\text { Sample } \\
\text { period }\end{array}$} & \multicolumn{2}{|c|}{ Model 1} & \multicolumn{2}{|c|}{ Model 2} & \multicolumn{2}{|c|}{ Model 3} & \multicolumn{2}{|c|}{ Model 4} & \multicolumn{3}{|c|}{ Model 5} \\
\hline & & onstant & OJE & stant & OJE & stant & OJE & stant & OJE & & OJE & all \\
\hline & \multirow{2}{*}{$\begin{array}{c}2002- \\
2018\end{array}$} & & 89 & 59 & 0.392572 & 09659 & 0.071892 & -0.207165 & 1.546905 & 0.000192 & 0.071892 & 8933 \\
\hline & & & .4042) & 8) & 6) & 6) & 6) & 12) & 8) & $.9807)$ & 6) & 5) \\
\hline & & & 001704 & 0.210386 & -0.321553 & -0.001539 & 133 & 822 & 809 & 475 & 35 & 77 \\
\hline & & & & (0.8998) & 5) & 9) & 8) & В) & 4) & 5) & $x_{1}$ & (0.4053) \\
\hline & & & 99 & & & & & & 73 & 04 & 0.00 & 0.0015 \\
\hline & & & . 8723$)$ & $(0.9668)$ & (0.8952) & & * & & b) & $(0.000)$ & $(0.8345)$ & (0.5153) \\
\hline \multirow{2}{*}{ Kuwait } & & & 0.017523 & $-c$ & 878 & 0.00 & 0.107076 & -0.0 & 5.782985 & 0.001037 & 0.00 & $0 . c$ \\
\hline & & & $(0.0017)^{*}$ & & & & $(0.039)^{*}$ & & (0.6901) & & $(0.8886)$ & )* \\
\hline \multirow{2}{*}{ Oman } & & & 25854 & 68 & 7 & 62 & 1.176087 & -0 & 8.7 & 0.00041 & -0 & -0 . \\
\hline & & The & & (0.9419) & $(0.9262)$ & $(0.3272)$ & 1) : & 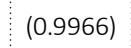 & 4) & 0) & (0.9995) & (0.9913) \\
\hline \multirow{2}{*}{ Qat } & \multirow{2}{*}{$\begin{array}{l}2001- \\
2018\end{array}$} & 2 & .001716 & -0.0768 & 0.199643 & 0.00 & 0.073 & 0.1 & 5.27 & 0.0 & 54 & 0 \\
\hline & & $(0.0000)$ & .2270) & $(0.9386)$ & (0.9103) & $(0.0828)$ & & & 4) & 7) & $(0.417)$ & 10 \\
\hline \multirow{2}{*}{$\begin{array}{l}\text { Saudi } \\
\text { Arabia }\end{array}$} & & 0.002865 & 0.009294 & 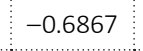 & 1 & 0 & 0. & 4 & 2.328 & 1 & 6 & 0.019 \\
\hline & & (0.4898) & 297) & 3) & 5042) & 156) & $(0.7594)$ & $(0.9847)$ & $(0.9079)$ & $(0.6822)$ & $(0.4234)$ & 0.001 \\
\hline
\end{tabular}

\section{Model 4}

$$
R_{t}^{F e b_{t}-J^{2 a n_{t+1}}}=a+b R_{t}^{\mathrm{Jan}}+e_{t} .
$$

Here we run the same regression as in Model 2, but with independent variable $R_{t}^{\text {Jan }}$ instead of $D$. However, it is not supported in the GCC markets.

Another area of interest is the interaction of different calendar anomalies, addressed by Jacobs and Levy (1988). A market anomaly recently investigated is the Halloween anomaly, which amounts to a "sell in May and go away" strategy (Bouman \& Jacobsen, 2002). Here also the empirical evidence found mixed results in international markets (Maberly \& Pierce, 2004). It is possible that investors who did not invest in a positive January-year will buy in November following the Halloween index and, thus, the January effect may be simply the Halloween effect in disguise. In Model 5 , we investigate whether the OJE is simply the Halloween effect in disguise. That is, we test the case that possibly the investors who do not follow the OJE strategy will buy in November following the Halloween index. Thus, the January effect may be simply the Halloween effect in disguise.

\section{Model 5}

$$
R_{t}^{\text {Feb-Dec }}=a+b_{1} R_{t}^{\text {Jan }}+b_{2} \text { HallD }_{t}+e_{t} .
$$

Since the predictive power of January might be related to other variables and phenomena or market anomalies, a test of the independent vector as the Halloween market anomaly is applied. According to this effect, returns for May to October are significantly lower than for the rest of the year. Hence, the Halloween indicator variable HallD takes the value 1 for each month from November to April and 0 for the remaining months. If $b_{2}$ is significant and $b_{1}$ is not, it would state that the Halloween effect is causing the January effect. The results are presented in Table 4 and show that the Halloween effect is not related to the predictive power of January. We observe that for the markets of Kuwait and Saudi Arabia, $b_{2}$ is significant and $b_{1}$ is not confirming the hypothesis that the Halloween effect is causing the OJE in these markets.

\section{CONCLUSION}

The objective of this paper is to empirically test whether the January barometer has a predictive power over the remainder of the year in the GCC stock exchanges. The results obtained indicate that January anomaly does not have a predictive power in all stock exchanges sampled in this study. While there are 
markets in which the traditional January effect continues to exist, there seems to be a worldwide tendency for it to steadily break. It was also observed that there was an inverse result when it came to comparing the returns of January to that of December, where returns were lower in January than in other months. Our results do not confirm the January anomaly in the GCC stock exchanges. Considering this evidence, one has to conclude that the other January effect is not an international phenomenon and that the existence and power of the January barometer varies between the stock markets.

In fact, some evidence is found for the Kuwait stock market, which confirms previous reported findings (Al-Saad, 2004) and for the Dubai Stock Exchange. However, for Kuwait and Saudi Arabia, we provide an additional explanation that the January effect may be the Halloween effect in disguise.

Market anomalies and calendar effects is an open agenda in market finance literature and much work is to be done. The present paper provided evidence against the other January effect in 7 countries of the Gulf region. As a future work and for further examining the robustness of the findings, one has to consider macroeconomic and market variables such as dividends and interest rates. Also, relating to the geographic area studied in this paper, of great interest would be to check the predictive power of January by using region's Muslim calendar ${ }^{5}$. Finally, the advance of a "buy and sell" strategy following January anomaly would be of great interest for investors.

\section{REFERENCES}

1. Al-Saad, K. (2004). Seasonality in the Kuwait Stock Exchange. Savings and Development, 28(4), 359-374. Retrieved from https://www.jstor. org/stable/25830874

2. Aly, H., Mehdian, S., \& Perry, M. J. (2004). An analysis of day-of-theweek effects in the Egyptian stock market. International Journal of Business, 9(3), 301-308. Retrieved from https://www.asc.ohio-state. edu/aly.1/docs/Aly-Mehdian-Perry's\%20paper.pdf

3. Arshad, Z., \& Coutts, J. A. (1997). Security price anomalies in the London International Stock Exchange: A 60-year perspective. Applied Financial Economics, 7(5), 455-464. https://doi. org/10.1080/096031097333312

4. Ball, R. (1994). The Development, Accomplishments and Limitations of the Theory of Stock Market Efficiency. Managerial Finance, 20(2), 3-48. https://doi.org/10.1108/ eb018462

5. Bley, J., \& Chen, K. H. (2006). Gulf Cooperation Council (GCC) stock markets: The dawn of a new era. Global Finance Journal, 17(1), 75-91. https://doi.org/10.1016/j. gf. 2006.06.009
6. Bloch, H., \& Pupp, R. (1983). The January Barometer revisited and rejected. The Journal of Portfolio Management, 9(2), 48-50. https:// doi.org/10.3905/jpm.1983.408909

7. Bohl, M. T., \& Salm, C. A. (2010). The Other January Effect: International Evidence. European Journal of Finance, 16(2), 173-182. https://doi. org/10.1080/13518470903037953

8. Bouman, S., \& Jacobsen, B. (2002) The Halloween Indicator, "Sell in May and Go Away": Another Puzzle. American Economic Review, 92(5), 1618-1635. Retrieved from https:// www.jstor.org/stable/3083268

9. Brown, L. D., \& Luo, L. (2006). The January Barometer: Further Evidence. Journal of Investing, 15(1). http://dx.doi.org/10.2139/ ssrn. 593121

10. Bulter, K. C., \& Malaikah, J. (1992). Efficiency and Inefficiency in Thinly Traded Stock Markets: Kuwait and Saudi Arabia. Journal of Banking and Finance, 16(1), 197-210.

Retrieved from https://econpapers. repec.org/article/eeejbfina/v_3a16_3ay_3a1992_3ai_3a1_3ap_ 3a197-210.htm

11. Chaffai, M., \& Medhioub, I. (2018). Herding behavior in Islamic GCC stock market: a daily analysis. International Journal of Islamic and Middle Eastern Finance and Management, 11(2), 182-193. https://doi.org/10.1108/IMEFM-08-2017-0220

12. Claessens, S., Dooley, M. P., \& Warner, A. (1995). Portfolio capital flows: Hot or cold? World Bank Economic Review, 9(1), 153-174. https://doi.org/10.1093/ wber/9.1.153

13. Cooper, M. J., Mcconnell, J. J., \& Ovtchinnikov, A. V. (2006). The Other January Effect. Journal of Financial Economics, 82(2), 315-341. https://doi.org/10.1016/j.jineco.2006.03.00

14. Darrat, A. F., Li, B., \& Chung, R. (2013). The Other Month Effect: A Re-Examination of the "Other January" Anomaly. Review of Pacific Basin Financial Markets and Policies, 16(02), 1-23. https://doi. org/10.1142/S0219091513500112

15. Dodd, O., \& Gakhovich, A. (2011). The holiday effect in Central and Eastern European financial markets. Investment Management and Financial Innovations, 8(4), 29-35. Retrieved from https://businessperspectives.org/images/pdf/applications/publishing/templates/article/ assets/4323/imfi_en_2011_04 Dodd.pdf

5 We thank an anonymous reviewer for this observation. 
16. Ebid, S. (1990). Characteristics and behavior of UAE stock market. Journal of Economic and Administrative Sciences, 6, 19-61.

17. Fuller, R. J. (1978). The January Barometer: What's Its Batting Average. The Journal of Portfolio Management, 4(2), 5-7.

18. Harshita, Singh, S., \& Yadav, S. S. (2019). Unique calendar effects in the Indian stock market: Evidence and explanations. Journal of Emerging Market Finance, 18(1), 35-58. https://doi. org/10.1177/0972652719831549

19. Haug, M., \& Hirschey, M. (2006). The January effect. Financial Analysts Journal, 62(5), 78-88. Retrieved from https://www.jstor. org/stable/4480774

20. Haugen, R. A., \& Jorion, P. (1996). The January effect: Still there after all these years. Financial Analysts Journal, 52(1), 27-31. https://doi. org/10.2469/faj.v52.n1.1963

21. Haugen, R. A., \& Lakonishok, J. (1988). The incredible January effect: the stock market's unsolved mystery. Homewood, Illinois: Dow Jones-Irwin. Retrieved from https://searchworks.stanford.edu/ view/10025446

22. Hirsch, Y. (1974). Stock trader's almanac. The Hirsch Organization, Nyack, NY.

23. Hirsch, J., \& Hirsch,Y. (2007). Stock trader's almanac. J. Wiley and Sons.

24. Jacobs, B. I., \& Levy, K. N. (1988). Calendar Anomalies: Abnormal Returns at Calendar Turning Points. Financial Analysts Journal, 44(6), 28-39. https://doi.org/10.2469/faj. v44.n6.28

25. Kinney, J. W., \& Rozeff, M. S. (1976). Time-Stratified Estimates of Portfolio Betas and Their Effect on the Capital Asset Pricing Model. Journal of Financial Economics, 3(4), 379-402. https://doi.org/10.2139/ ssrn. 903303

26. Leontitsis, A., \& Siriopoulos, C. (2006a). Calendar Corrected Chaotic Forecast of Financial Time Series. International Journal of Business, 11(4), 367-374. Retrieved from https://www.researchgate.net/ publication/242737998_Calendar_ Corrected_Chaotic_Forecast_of_Fi-
nancial_Time_Series

27. Leontitsis, A., \& Siriopoulos, C. (2006b). Nonlinear forecast of financial time series through dynamical calendar correction. Applied Financial Economics Letters, 2(5), 337-340. https://doi. org/10.1080/17446540500461786

28. Maberly, E. D., \& Pierce, R. M. (2004). Stock Market Efficiency Withstands another Challenge: Solving the "Sell in May/Buy after Halloween" Puzzle. Economic Journal Watch, 1(1), 29-46. Retrieved from https://econjwatch. org/articles/stock-market-efficiency-withstands-another-challengesolving-the-sell-in-may-buy-afterhalloween-puzzle

29. Marshall, \& Visaltanachoti, (2010). The Other January Effect: Evidence against market efficiency? Journal of Banking and Finance, 34(10), 2413-2424. https://doi.org/10.1016/j. jbankfin.2010.03.019

30. Mills, T. C., Siriopoulos, C., Markellos, R. N., \& Harizanis, D. (2000). Seasonality in the Athens stock exchange. Applied Financial Economics, 10(2), 137-142. https:// doi.org/10.1080/096031000331761

31. Nourredine, K. (1998). Behavior of Stock Prices in the Saudi Arabian Financial Market: Empirical Research Findings. Journal of Financial Management and Analysis, 11(1), 48-55. Retrieved from https://www.questia.com/library/ journal/1P3-34570740/behavior-ofstock-prices-in-the-saudi-arabianfinancial

32. Patel, J. B. (2012). A further analysis of small firm stock returns. Managerial Finance, 38(7), 653659. Retrieved from https://ideas. repec.org/a/eme/mfipps/v38y2012i7p653-659.htm

33. Patel, J. B. (2015). The January Effect Anomaly Reexamined in Stock Returns. Journal of Applied Business Research, 32(1), 317. https://doi. org/10.19030/jabr.v32i1.9540

34. Plastun, A., Sibande, X., Gupta, R., \& Wohar, M. E. (2019). Rise and fall of calendar anomalies over a century. The North American Journal of Economics and Finance, 49, 181-205. https://doi. org/10.1016/j.najef.2019.04.011
35. PWC Middle East. (2019). GCC capital markets watch, Q2. Retrieved from https://www.pwc.com/m1/en/ publications/capital-markets-watch. html

36. Ritter, J. R. (1988). The Buying and Selling Behavior of Individual Investors at the Turn of the Year. Journal of Finance, 43(3), 701-719. https://doi.org/10.2307/2328193

37. Schwert, G. (2002). Anomalies and market efficiency (NBER Working Paper No. 9277). Cambridge, MA: National bureau of economic research. https://doi.org/10.3386/ w9277

38. Stivers, C., Sun, L., \& Sun, Y. (2009). The other January effect: International, style, and subperiod evidence. Journal of Financial Markets, 12(3), 521-546. https://doi. org/10.1016/j.finmar.2009.01.001

39. Wachtel, S. B. (1942). Certain observations on seasonal movements in stock prices. The journal of Business of the University of Chicago, 15(2), 184-193. http:// dx.doi.org/10.1086/232617

40. Washer, K. N., Nippani, S., \& Johnson, R. (2016). Santa Claus Rally and firm size. Managerial Finance, 42(8), 817-829. http:// dx.doi.org/10.1108/MF-10-20150280

41. Zarour, B. (2006). The efficiency of Arab stock markets, its interrelationships and interactions with developed and developing stock markets (Ph.D. Thesis). School of Business, University of Patras. Retrieved from http://roar.eprints. org/919/

42. Zarour, B. (2007). The Halloween Effect Anomaly: Evidence from the MENA Equity Markets. Studies in Business and Economics, 13(1), 68-76. Retrieved from https://pdfs. semanticscholar.org/be95/740d313 a6562f45751ed03c4a7685cbd2430. pdf

43. Zarour, B., \& Siriopoulos, C. (2008). Transitory and Permanent Volatility Components: The Case of the Middle East Stock Markets. Review of Middle East Economics and Finance, 4(2), 80-92. Retrieved from https://ideas.repec.org/a/bpj/ rmeecf/v4y2008i2n3.html 